\title{
Ancaman keanekaragaman hayati (Biodiversity) terhadap ekosistem daerah penangkapan pukat hela
}

\author{
Fauzan Ramadan, Farhan Ramdhani, Deni Efizon, Nofrizal ${ }^{*}$ \\ Program magister Ilmu Kelautan, Fakultas Perikanan dan Ilmu Kelautan, Universitas Riau, Kampus Bina \\ Widya, KM 12,5, Simpang Panam, Pekanbaru 28293, Indonesia. \\ Korespondensi author: aan_fish@yahoo.com
}

(Diterima 21 Januari 2020|Disetujui 9 Juli 2020|Diterbitkan 30 Juli 2020)

\begin{abstract}
Trawl has the size a mesh size a small size pockets of the cod end. This allows the trawl fishing gear to potentially be a fishing gear that is not selective about the size of the fish and the spesies that are targeted for its catch. If this fishing gear is left, its existence will eventually have a negative impact on the sustainability of fish resources, especially in coastal waters. The purpose of this study is to calculate the composition and proportion of main catches, bycatch and discarded catches. It is expected that knowing the composition and proportion of the main, by-product and discarded catches can provide an overview of the pressure on stocks and sustainability of fisheries resources in the waters where trawl is operated. This study was conducted in April 2019 at Kuala Tungkal, Tungkal Ilir District, Tanjung Jabung Barat Regency. The method used in this study is a survey method. A series of survey activities were carried out directly in the field to identify and count the types of spesies caught by trawlers. Based on the percentage of main catch, by-catch and discard per type, it Matuta planipes are the dominant spesies caught by trawlers (23.65\%). The main catch Parapenaeus longirostris 15.92\%. In addition, the main catch caught were Parapenaeopsis sculptilis (9.787\%), Penaeus merguiensis (0.646\%), Metapenaeus brevicornis (10.118\%), Penaeus indicus (0.029\%) and Squilla mantis (0.153\%). Percentage of bycatch reaches $2.245 \%$ of 10 spesies caught and discarded catches reach $61.103 \%$ of 25 spesies caught.
\end{abstract}

Keywords: main catch, by-catch, discard, trawl, fish resources

Pukat Hela (Trawl mini) merupakan alat tangkap yang berbentuk empat persegi ataupun kerucut, dua lembar saya (wing), dihubungkan dengan tali penarik (warp). Jaring ini ditarik horizontal di dalam air karena mendapat/menerima tahanan dari air mulut jaring terbuka: keadaan ini diusahakan agar tetap terpelihara selama operasi dilakukan, Ayodhyoa (1981). Dalam mulut jaring yang dibatasi oleh head rope dan ground rope ini diharapkan agar ikan-ikan dan makhluk lain yang menjadi tujuan penangkapan dapat masuk bersama air yang tersaring, dengan ikan-ikan dapat tertangkap.

Alat tangkap yang ramah lingkungan hendaknya memiliki selektivitas yang tinggi. Alat penangkapan ikan diharapkan selektif ter-hadap ukuran maupun juga selektif terhadap spesies yang menjadi sasaran utama alat tang-kap tersebut. Alat penangkapan ikan yang tidak selektif tentunya berpengaruh terhadap komu-nitas dan populasi ikan diperairan. Sehingga pada akhirnya berdampak terhadap stok ikan diperairan atau daerah penangkapan ikan ter-sebut. Pukat Hela demersal merupakan alat tangkap yang umum digunakan pada perikanan skala industri tetapi juga oleh nelayannelayan kecil. Jumlah bycatch dan discards ditaksir sekitar 332.186 ton/tahun Purbayanto et al. (2004). Tidak semua hasil tangkapan sampingan dibuang, hanya ikan-ikan yang tidak bernilai ekonomis yang dibuang baik dalam kondisi hidup maupun mati. Selain karena tidak bernilai ekonomis, peraturan juga melarang nelayan mendaratkan hasil tangkapan sampingan. Hal ini dilakukan untuk menekan jumlah hasil tang-kapan sampingan yang dihasilkan dari proses penangkapan yang tidak berwawasan lingkungan.

Hasil kajian Eayrs (2005), menyebutkan bahwa FAO mengestimasi sebanyak lebih kurang 7 ton hasil tangkapan sampingan dibu-ang kelaut oleh nelayan komersial setiap tahun-nya. Kemungkinan hasil tangkapan sampingan alat tangkap gombang termasuk ke dalam data tersebut. FAO Code of Conduct of Responsible Fisheries praktis mengupayakan untuk mewa-jibkan nelayan di seluruh dunia menekan jumlah hasil tangkapan sampingan dan dampak lingkungan yang diakibatkan dari metode penangkapannya. Secara spesifik, peraturan ini mengharuskan semua negara di dunia untuk menerapkan prinsip dasar pengelolaan perikan-an yang berkelanjutan (Fisheries Sustainable Management).

Pukat hela adalah alat tangkap yang dilarang dioperasikan berdasarkan peraturan menteri nomor 02/PERMEN-KP/2015 yang menyatakan bahwa alat tangkap yang sifatnya ditarik dilarang untuk dioperasikan. Pukat hela merupakan salah satu alat tangkap yang dioperasikan nelayan yang berada di Kabupaten Tanjung Jabung Barat khususnya daerah Kuala Tungkal. Pada tahun 2016 berdasarkan data Dinas Kelautan dan Perikanan setempat jumlah alat tangkap pukat hela (trawl mini) sebanyak 162 unit yang terdiri dari 79 alat penggaruk berkapal (trawl) dan 83 pukat hela pertengahan. Pada tahun 2018-2019 penggunaan alat tangkap pukat hela berkurang karena adanya pelarangan penggunaan pukat hela di daerah tersebut. Rancangan alat tangkap pukat hela (trawl mini) berbentuk kerucut dengan ukuran mata pada bagian kantong sangat kecil yaitu $1 \mathrm{~cm}$. Hal ini memungkinkan alat tangkap pukat hela yang 
dioperasikan berpotensi mnjadi alat tangkap yang tidak selektif terhadap ukuran ikan dan jenis yang menjadi sasaran tangkapannya.

Sejauh ini belum ada kajian yang memastikan bagaimana sebenarnya komposisi hasil tangkapan alat tangkap pukat hela tersebut. Oleh karena itu, penelitian ini bertujuan untuk mengidentifikasi komposisi dan proporsi hasil tangkapan utama, sampingan dan yang dibuang pada alat tangkap pukat hela (trawl mini). Tentunya hal ini diharapkan akan menjadi dasar kajian-kajian yang berkaitanselanjutnya mengenai teknologi penangkapan ikan ramah lingkungan dimasa mendatang.

\section{BAHAN DAN METODE}

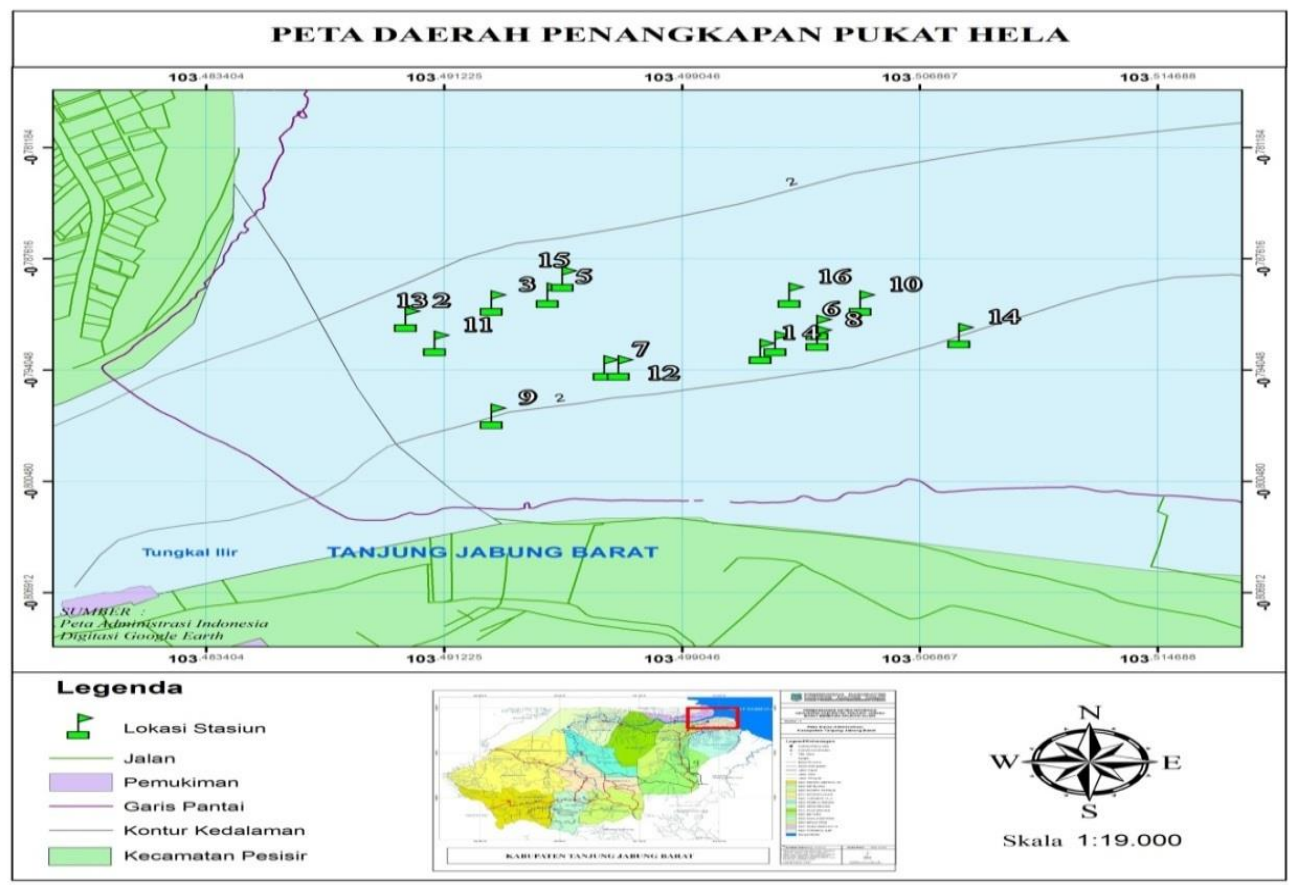

Gambar 1. Lokasi Penelitian

Pengambilan data hasil tangkapan alat tangkap pukat hela menggunakan metode propulsif sampling, yaitu diambil 4 unit alat tangkap pukat hela jadi jumlah populasi alat tangkap pukat hela yang ada di Perairan Kuala Tungkal dengan ukuran alat tangkap yang sama. Diharapkan dari pemilihan alat tangkap ini dapat menghasilkan data yang representatif dalam menggambarkan proporsi dan komposisi hasil tangkapan dari alat tangkap pukat hela (trawl mini).

Penetapan hasil tangkapan utama (main catch), sampingan (by-catch) dan dibuang (discard) berdasarkan wawancara terhadap nelayan. Hasil tangkapan utama merupakan hasil tangkapan yang diinginkan oleh nelayan. Hasil tangkapan sampingan merupakan hasil tangkapan yang tidak diinginkan oleh nelayan, tetapi ada sebagian hasil tangkapan sampingan memiliki nilai ekonomis yang tinggi dan ada pula sebahagian hasil tangkapan itu dibuang.

Total hasil tangkapan dari setiap alat tangkap pukat hela yang digunakan dikumpulkan, kemudian
Metode yang digunakan adalah metode survey yaitu pengamatan langsung di perairan penangkapan dengan cara mengidentifikasi jenis spesies dan menghitung jumlah spesies yang tertangkap oleh alat tangkap pukat hela (trawl mini). Penelitian ini dilakukan pada bulan April 2019 di Perairan Kuala Tungkal, Kecamatan Tungkal Ilir Kabupaten Tanjung Jabung Barat. Penetapan lokasi penangkapan berdasarkan dominasi penyebaran alat tangkap pukat hela (trawl mini) di Kabupaten Tanjung Jabung Barat. Pemilihan lokasi tersebut diharapkan dapat menggambarkan proporsi dan komposisi hasil tangkapan perikanan pukat hela yang refresentatif di Kabupaten Tanjung Jabung Barat. 
$(<15 \%)$. Seluruh persentasi hasil tangkapan yang diperoleh tersebut selanjutnya akan ditabulasikan dalam bentuk Tabel dan Grafik. Sedangkan untuk analisis keragaman masing-masing hasil tangkapan yang diperoleh alat tangkap Pukat Hela akan menggunakan uji F. Uji F tersebut dilakuan agar dapat melihat keragaman rata-rata setiap spesies yang tertangkap setiap kali penarikan alat tangkap (hauling), dari seluruh sampel alat tangkap Pukat Hela akan diamati. Sehingga dapat menajawab hipotesis'hasil tangkapan Pukat Hela memiliki keragaman jenis'. Adapun pendekatan persamaan uji $\mathrm{F}$ sebagai berikut:

$$
F=\frac{\frac{R^{2}}{k}}{\left(1-R^{2}(n-k-1)\right.}
$$

Dimana:

$$
\begin{array}{ll}
R^{2} & \text { Koefisien regresi } \\
n & =\text { Jumlah seluruh sampel ikan hasil } \\
& \text { tangkapan Pukat Hela } \\
k & =\text { Jumlah setiap spesies tertangkap }
\end{array}
$$

$$
\begin{aligned}
& \text { HTU }(\%)=\frac{H T U}{\text { Total hasil tangkapam }} \times 100 \% \\
& \text { HTS }(\%)=\frac{\text { HTS }}{\text { Total hasil tangkapam }} \times 100 \%
\end{aligned}
$$

Keterangan :

HTU : Hasil tangkapan utama

HTS : Hasil tangkapan sampingan

Data hasil tangkapan yang didaratkan dari unit penangkapan Pukat Hela dikelompokkan dalam dua kategori, yaitu hasil tangkapan utama dan hasil tangkapan sampingan. Hasil tangkapan sampingan terbagi menjadi hasil tangkapan sampingan yang bernilai ekonomis tinggi dan hasil tangkapan sampingan yang bernilai ekonomis rendah dan yang dibuang kelaut.

\section{HASIL}

Data komposisi hasil tangkapan keseluruhan alat tangkap pukat hela (trawl mini) terdapat 41 jenis hasil tangkapan yang terdiri dari 6 jenis hasil tangkapan utama, 10 hasil tangkapan sampingan yang masih memiliki nilai ekonomis tinggi dan 25 jenis yang dibuang (Tabel 1). Tabel 1 menunjukkan hasil tangkapan pukat hela dari 41 spesies yang berjumlah 123.823 ekor selama 28 kali setting dan hauling. Hasil tangkapan tertinggi yaitu sebesar 29.281 ekor kepiting belang (Matuta planipes) yang termasuk dalam hasil tangkapan sampingan. Hasil tangkapan utama pukat hela adalah sebesar 45.383 ekor yaitu jenis udangudangan antara lain: udang loreng (Parapenaeopsis sculptilis) 12.119 ekor, udang merah (Parapenaeus longirostris) 19.711 ekor, udang peci ( $\underline{\text { Penaeus }}$ merguiensis) 800 ekor, udang kuning (Metapenaeus brevicornis) 12528 ekor, udang agogo (Penaeus indicus) 36 ekor, dan udang mantis (Squilla mantis) 189 ekor.

Rata-rata hasil tangkapan yang dibuang (discard) dalam perikanan pukat hela (trawl mini) per unit dan per upaya penangkapan signifikan lebih tinggi dibandingkan hasil tangkapan utama (main catch) dan sampingan (by-catch) $(\mathrm{F}<0,05)$. Rata-rata laju hasil tangkapan per unit an per upaya penangkapan menunjukan kepiting belang (Matuta planipes) lebih tinggi daripada jenis ikan dan crustacea lainnya $(\mathrm{F}<0,05)$.

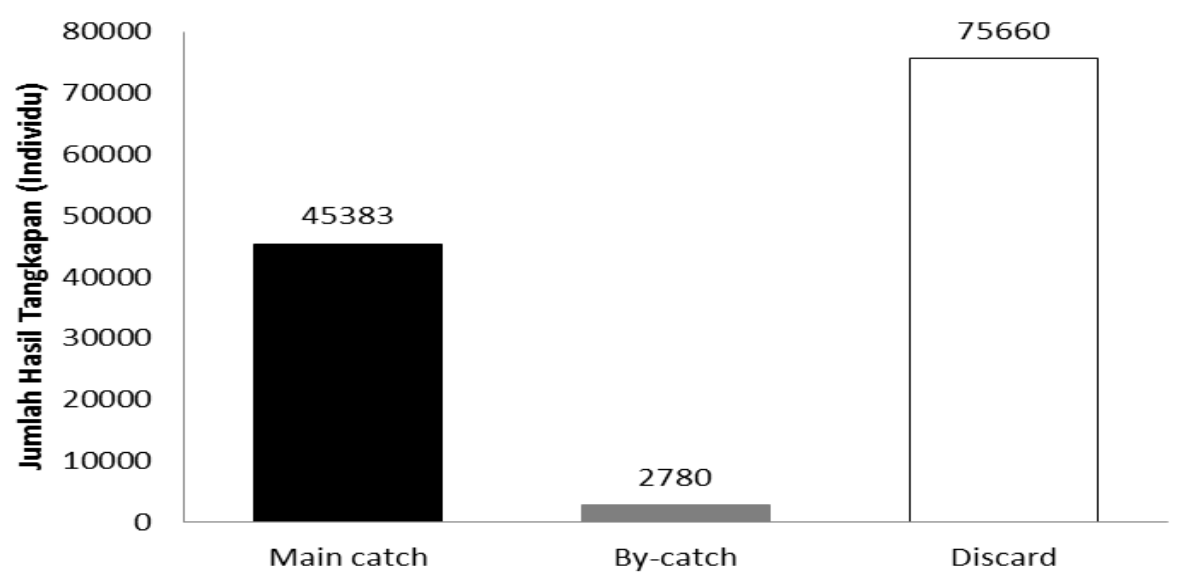

Gambar 2. Perbandingan jumlah hasil tangkapan utama,sampingan dan yang dibuang 


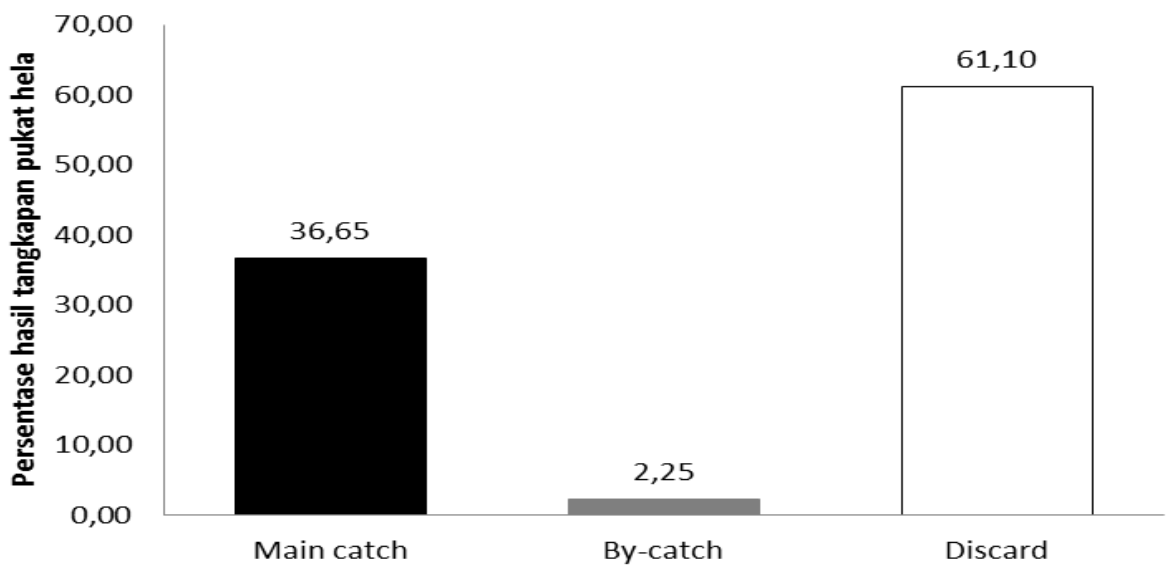

Gambar 3. Persentase hasil tangkapan utama (main catch), Sampingan (by-catch) dan yang dibuang (discard)

Tabel 1. Komposisi hasil tangkapan alat tangkap pukat hela (trawl mini)

\begin{tabular}{|c|c|c|c|c|c|}
\hline \multirow[t]{2}{*}{ No } & \multicolumn{2}{|r|}{ Jenis Spesies } & \multirow[t]{2}{*}{ Ekor } & \multirow[t]{2}{*}{$(\%)$} & \multirow[t]{2}{*}{ Keterangan } \\
\hline & Nama lokal & Nama latin & & & \\
\hline 1 & Udang Loreng & Parapenaeopsis sculptilis & 12119 & 9,79 & Main cacth \\
\hline 2 & Udang Merah & Parapenaeus longirostris & 19711 & 15,92 & Main cacth \\
\hline 3 & Udang Peci & Penaeus merguiensis & 800 & 0,65 & Main cacth \\
\hline 4 & Udang Kuning & Metapenaeus brevicornis & 12528 & 10,12 & Main cacth \\
\hline 5 & Udang Agogo & Penaeus indicus & 36 & 0,03 & Main cacth \\
\hline 6 & Udang mantis & Squilla mantis & 189 & 0,15 & Main cacth \\
\hline 7 & Ikan Bawal putih & Pampus argenteus & 40 & 0,03 & By-catch \\
\hline 8 & Ikan Bawal Bintang & Trachinotus blochii & 34 & 0,03 & By-catch \\
\hline 9 & Ikan Bawal Hitam & Parastromateus niger & 4 & 0,00 & By-catch \\
\hline 10 & Ikan Malung & Muarenesox cinereus & 219 & 0,18 & By-catch \\
\hline 11 & Ikan senangin & polynemus tetradactylus & 24 & 0,02 & By-catch \\
\hline 12 & Ikan Sembilang & Paraplotosus albilabris & 49 & 0,04 & By-catch \\
\hline 13 & Kepiting Bakau & Scylla spp & 30 & 0,02 & By-catch \\
\hline 14 & Ikan Puput & Ilisha megaloptera & 1077 & 0,87 & By-catch \\
\hline 15 & Ikan Lomek & Harpodon neherus & 1223 & 0,99 & By-catch \\
\hline 16 & Ikan Pari & Dasyatis $s p$ & 80 & 0,06 & By-catch \\
\hline 17 & Udang Galah & Macrobrachium rosenbergi & 20 & 0,02 & Discard \\
\hline 18 & Ikan layur & Trichiurus lepturus & 1723 & 1,39 & Discard \\
\hline 19 & Ikan gulama & Otolithoides biauritus & 3006 & 2,43 & Discard \\
\hline 20 & Ikan beliak mata & Ilisha elongate & 2988 & 2,41 & Discard \\
\hline 21 & Ikan selangat & Anadontosoma chacunda & 240 & 0,19 & Discard \\
\hline 22 & Ikan Duri & Arius maculaticus & 81 & 0,07 & Discard \\
\hline 23 & Ikan Buntal & Aratutron nigropunchtatus & 968 & 0,78 & Discard \\
\hline 24 & Kepiting Belang & Matuta planipes & 29281 & 23,65 & Discard \\
\hline 25 & Bintang laut & Pisaster brevispinus & 16 & 0,01 & Discard \\
\hline 26 & Ikan Bulu Ayam & Thryssa mystax & 7432 & 6,00 & Discard \\
\hline 27 & Ikan Gelodok & Periophthalmus gracilis & 416 & 0,34 & Discard \\
\hline 28 & Belut laut & Gymnothorax dorsalis & 184 & 0,15 & Discard \\
\hline 29 & Ikan Sebelah & Psettodes erumeri & 192 & 0,16 & Discard \\
\hline 30 & Ikan Lidah & Cynoglossus lingua & 212 & 0,17 & Discard \\
\hline 31 & Ikan Kitang & Scatophagus argus & 92 & 0,07 & Discard \\
\hline 32 & Ikan Sagai & Carangoides $s p$ & 62 & 0,05 & Discard \\
\hline 33 & Ikan Sulumeria & Harpadon microchir & 140 & 0,11 & Discard \\
\hline 34 & Ikan Tembang & Sardinella gibbosa & 5292 & 4,27 & Discard \\
\hline 35 & Ikan Bilis & Escualosa thoracata & 13092 & 10,57 & Discard \\
\hline 36 & Blankas & Carcinoscorpius rotundicauda & 297 & 0,24 & Discard \\
\hline 37 & Ular Laut & Hydrophidae sp & 90 & 0,07 & Discard \\
\hline 38 & Ubur Ubur & Aurelia aurita & 20 & 0,02 & Discard \\
\hline 39 & Udang Rebon & Sergestes similis & 8368 & 6,76 & Discard \\
\hline 40 & Ikan Lepuh & Pterois volitans & 136 & 0,11 & Discard \\
\hline 41. & Siput & Thecacera pacifica & 1312 & 1,06 & Discard \\
\hline & & otal & 123823 & 100 & \\
\hline
\end{tabular}




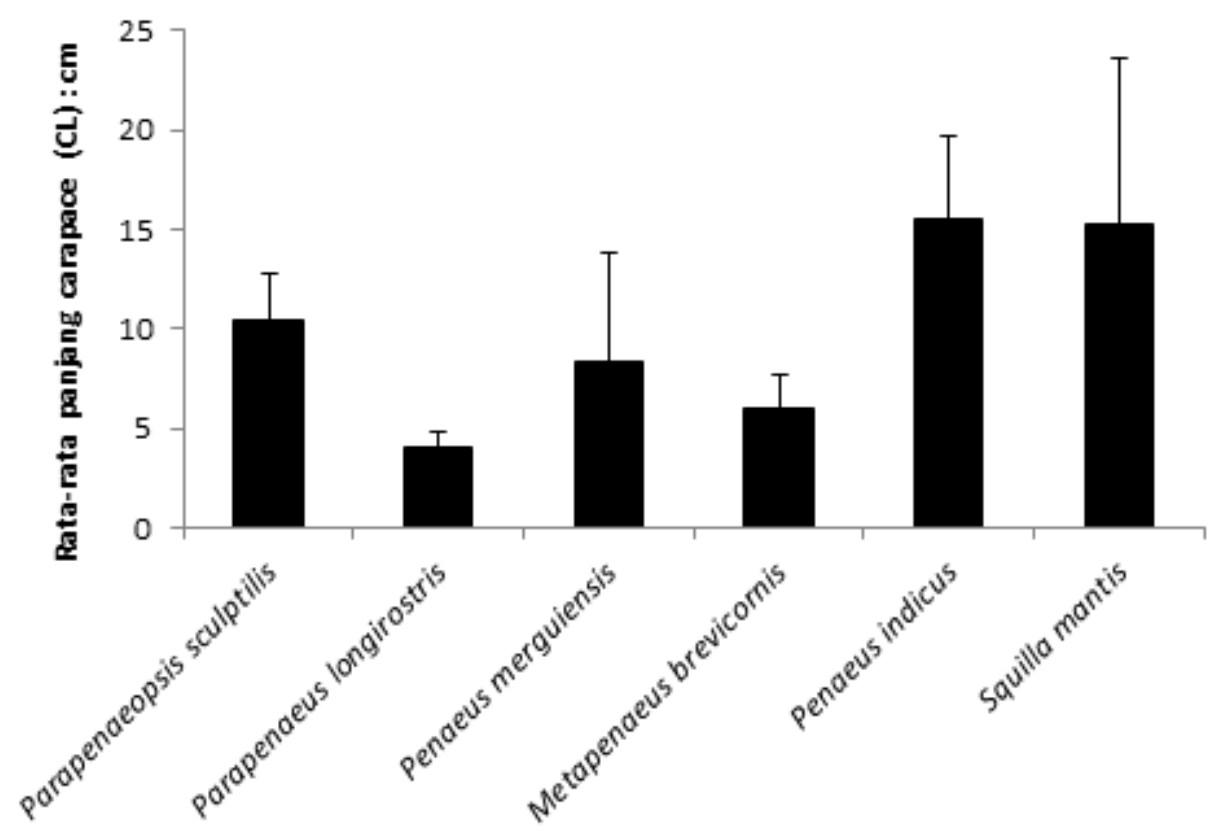

Gambar 4. Rata-rata ukuran hasil tangkapan utama (main catch)

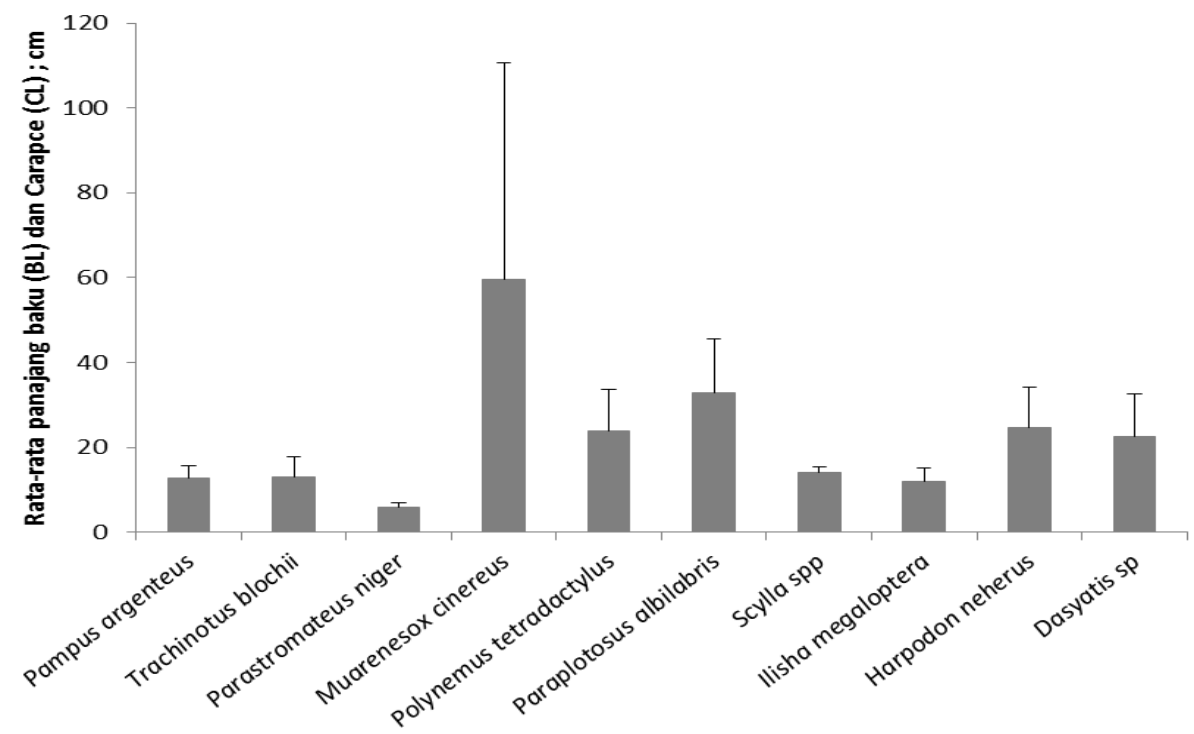

Gambar 5. Rata-rata ukuran hasil tangkapan sampingan (by-catch)

Gambar 2 menunjukkan hasil tangkapan individu pada alat tangkap pukat hela, histogram berwarna hitam menunjukkan hasil tangkapan utama, histogram berwana abu-abu menunjukkan hasil tangkapan sampingan, dan histogram tidak berwarna menunjukan hasil tangkapan yang dibuang. Perbandingan antara jumlah total hasil tangkapan utama, sampingan dan yang dibuang dari 28 kali melakukan setting dan hauling menunjukkan hasil tangkapan yang dibuang (discard) lebih banyak dibandingkan hasil tangkapan sampingan (by-catch) dan utama (main catch) yaitu sebanyak 75.660 ekor. Adapun hasil tangkapan sampingan berjumlah 2.780 ekor dan hasil tangkapan utama berjumlah 45.383 ekor. Begitu pula pada Gambar 3 menyatakan bahwa persentasi hasil tangkapan yang dibuang lebih tinggi dibandingkan hasil tangkapan utama dan sampingan yaitu sebesar $61,10 \%$.

Ukuran panjang tubuh ikan dan panjang tubuh carapace dan kepiting menjadi salah satu indikator untuk melihat tingkat kedewasaan pertama (first maturity). Rata-rata ukuran carapace lenght (CL) hasil tangkapan utama untuk jenis Parapenaeopsis sculptilis $10,4 \pm 2,42 \mathrm{~cm}$ (rata-rata \pm standar deviasi), untuk jenis Parapenaeus longirostris 4,08 $\pm 0,74 \mathrm{~cm}$, Penaeus merguiensis 8,34 $\pm 5,45 \mathrm{~cm}$, Metapenaeus brevicornis 5,94 $\pm 1,76 \mathrm{~cm}$, Penaeus indicus $15,58 \pm 4,14 \mathrm{~cm}$, dan Squilla mantis 15,28 $\pm 8,30 \mathrm{~cm}$ (Gambar 4).

Grafik histogram pada Gambar 4 menunjukan hasil tangkapan sampingan yang terdiri dari udang dan ikan. Ada beberapa jenis ikan yang belum masuk ke dalam tahapan tingkat kedewasaan (first maturity). Ada pun rata-rata hasil tangkapan sampingan alat tangkap pukat hela yang belum memasukin tingkat kedewasaan 
antara lain; Pampus argenteus 12,82 $\pm 2,90 \mathrm{~cm}$, Trachinotus blochii 13,04 $\pm 4,78 \mathrm{~cm}$, Parastromateus niger $5,98 \pm 0,82 \mathrm{~cm}$ dan

Rata-rata ukuran hasil tangkapan yang dibuang pada laat tangkap pukat hela lebih banyak secara individu dan ukurannya hasil tangkapannya lebih kecil dibandingkan hasil tangkapan utama dan sampingan. Jenis kepting belang (Matuta planipes) adalah hasil tangkapan paling banyak tertangkap dengan rata-rata ukuran yang tertangkap oleh alat tangkap pukat hela berukuran 5,66 $\pm 2,78 \mathrm{~cm}$, sedangkan ukuran dewasa spesies ini berukuran $10 \mathrm{~cm}$, jenis Arius maculaticus $10,74 \pm 4,81 \mathrm{~cm}$ dengan tingkat kedewasaan spesies ini $38 \mathrm{~cm}$, Scatophagus argus 7,7 $\pm 3,53 \mathrm{~cm}$ dengan tingkat kedewasaan $14 \mathrm{~cm}$, dan Escualosa thoracata 7,23 $\pm 1,25$ $\mathrm{cm}$ dengan tingkat kedewasaan spesies ini $12,8 \mathrm{~cm}$ (Gambar 6).

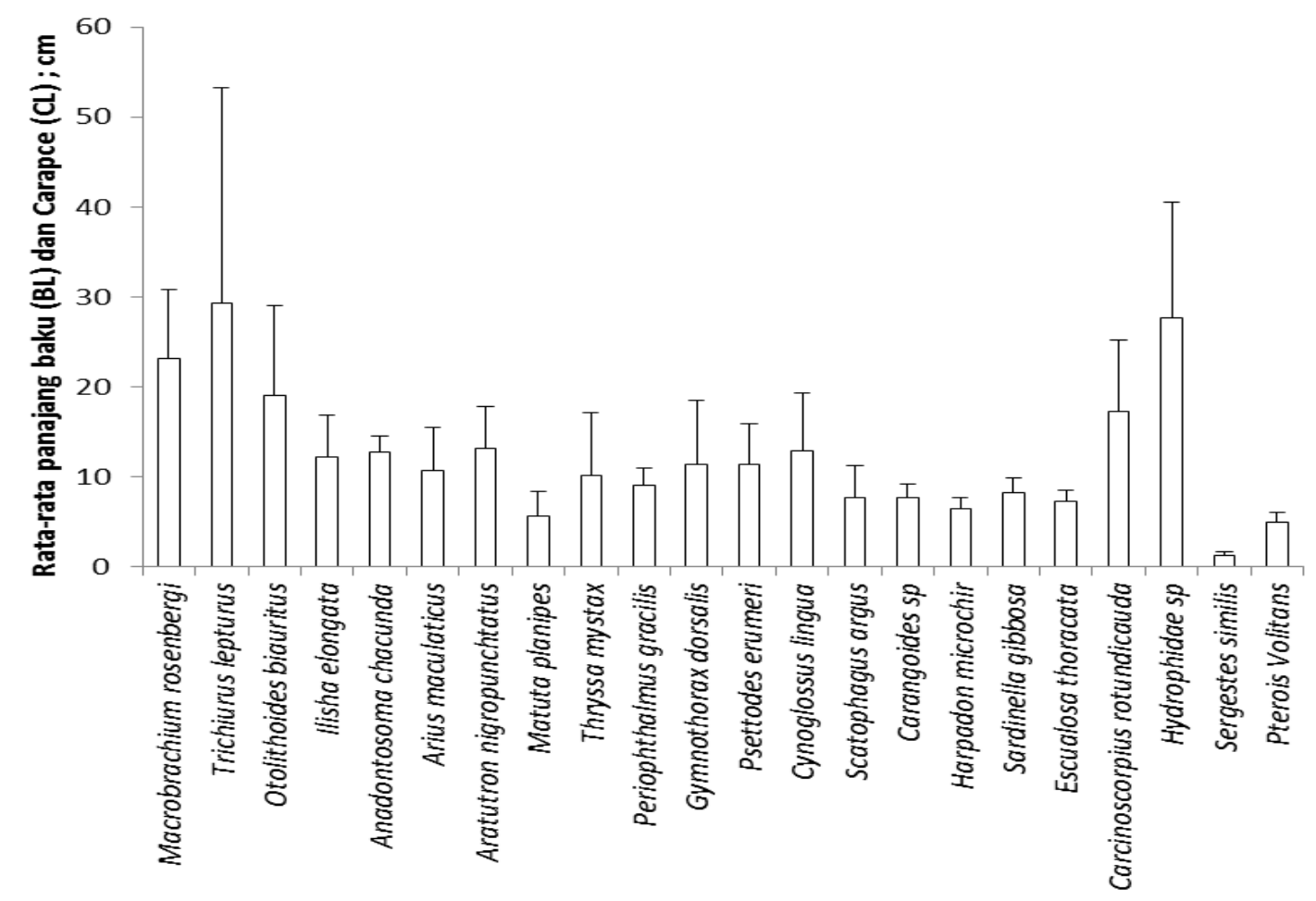

Gambar 6. Rata-rata ukuran hasil tangkapan yang dibuang (discard)

\section{PEMBAHASAN}

Kemampuan dan tingkah laku ikan renang ikan memegang peran penting dalam proses tertangkapnya ikan oleh tangkap ikan Nofrizal dan Arimoto (2017). Pada prinsipnya alat tangkap pukat hela dioperasikan dengan cara ditarik pada bagian buritan dan bagian badan kapal dengan kecepatan yang tinggi. Oleh karena itu, sebagian besar hasil tangkapan pukat hela masih banyak yang berukuran kecil dengan kemampuan renang yang rendah.

Gambar 2 dan 3 menunjukkan proporsi dan persentase hasil tangkapan pada alat tangkap pukat hela. Meskipun laju hasil tangkapan per unit alat tangkap pukat hela tinggi namun jenis hasil tangkapan sampingan dan yang dibuang pukat hela lebih banyak dibandingkan target utama pada alat tangkap tersebut. Hal serupa juga dilaporkan oleh Broadhurst et al. (2006) hasil tangkapan sampingan pada perikanan pukat di perairan tropis tidak proporsional dengan hasil tangkapan utama. Jenis hasil tangkapan sampingan lebih banyak dari pada hasil tangkapan utama. Hasil tangkapan sampingan merupakan bagian dari tangkapan nelayan yang tidak dike-hendaki atau bukan merupakan sasaran utama. Hasil tangkapan sampingan dibuang ke laut atau untuk konsumsi manusia dan hewan. Zeller dan Pauly (2005) menambahkan, hasil tangkapan sampingan yang dibuang menjadi permasalahan perikanan global. Tertangkapnya hasil tangkapan sampingan dapat menjadi ancaman bagi keanekaragaman spesies dan kelestarian lingkungan, sebab bagian dari tankapan ini biasanya tidak diatur. Dalam pengertian yang luas, hasil tangkapan sampingan mencakup semua hewan yang bukan merupakan sasaran utama bahkan termasuk benda-benda tidak hidup (sampah) yang tertangkap ketika melakukan operasi penangkapan Eayrs (2005).

Selanjutnya Eayrs (2005) mendefinisikan hasil tangkapan sampingan sebagai segala sesuatu yang bukan merupakan sasaran untuk ditangkap nelayan dan dapat terdiri dari penyu, ikan, kepiting, hiu, ikan pari, karang, rumput laut dan sampah dari dasar laut. Hasil tangkapan sampingan juga termasuk hewanhewan dan benda tidak hidup yang berinteraksi dengan alat tangkap tetapi tidak sampai ke atas geladak kapal 
ikan. Hall et al. (2000) menyatakan hasil tangkapan sampingan merupakan masalah yang dapat mempengaruhi keberlanjutan perikanan tangkap.

Komposisi jenis hasil tangkapan pada pukat hela sangat bervariasi, yaitu mencapai 41 jenis yang tertangkap (Tabel 1). Kondisi ini tentunya berpotensi untuk merusak keanekaragaman hayati dalam ekosistem perairan dimana alat tangkap tersebut dioperasikan. Hasil tangkapan sampingan juga telah menjadi perhatian utama untuk kegiatan konservasi (baik pemerintah dan non-pemerintah) masyarakat secara luas. Tentu saja profil, suara, dan pengaruh pada pendapat yang lebih luas dari hasil tangkapan sampingan tidak akan pernah kuat. Hasil tangkapan sampingan (by-catch) dan yang dibuang (discard) menjadi perhatian serius di level internasional. Hasil tangkapan sampingan tidak hanya mempengaruhi stok ikan di perairan, tetapi juga mempengaruhi rantai makanan dan habitat, dan pada akhirnya mengganggu dan merusak ekosistem Harrington et al. (2005).

Hasil tangkapan sampingan dan yang dibuang yang jumlahnya lebih dominan dari hasil tangkapan utama menunjukkan selektivitas alat tangkap rendah dan dapat mengakibatkan perubahan keanekaragaman hayati di suatu perairan. Nofrizal (2018). Eayrs (2005) hasil tangkapan yang dibuang adalah bagian dari hasil tangkapan sampingan yang dibuang atau dikembalikan ke laut dalam keadaan hidup atau mati. Termasuk semua hewan dan benda tidak hidup yang ter-sangkut dengan alat tangkap tetapi tidak sam-pai di geladak kapal. Hasil tangkapan samping-an yang dibuang terdiri dari spesies yang bernilai ekonomi rendah, spesies ikan komersial yang kecil-kecil, ikan muda dan sampah dari dasar laut. Nelayan biasanya membuang bagian dari tangkapan ini, sebab tidak ekonomis untuk di-simpan di kapal atau karena peraturan melarang jenis ikan ini didaratkan. Seringkali tang-kapan spesies yang komersial, melebihi kapasi-tas pengolahan atau penyimpanan di kapal penangkapan sehingga kelebihan ini harus dibuang Eayrs (2005) .

Vestergaard (1996) menyatakan hasil tangkapan yang dibuang biasanya terjadi karena kekuatan nilai ekonomis (spesies non komersial dan spesies bernilai ekonomi rendah, karena kondisi dan ukurannya) dan juga sebagai akibat langsung dari tindakan manajemen (ukuran minimum pendaratan dan pembatasan pendaratan). Hall et al. (2000) menyatakan dengan alasan paling umum untuk membuang hasil tangkapan sampingan adalah spesies bernilai komersial rendah, kondisi hasil tangkapan buruk dan tangkapan kecil (di bawah ukuran minimum ukuran pendaran legal). Masalah global dalam bidang perikanan Alverson et al. (1994). Membuang hasil tangkapan non-komersial dalam operasi penangkapan ikan di seluruh dunia adalah masalah yang telah menyita banyak perhatian

Hasil tangkapan sampingan yang tidak bernilai akan dibuang baik dalam keadaan hidup maupun dalam keadaan mati. Hal ini memicu permasalahan konservasi yang serius dikarenakan terbuangnya sumber daya alam yang berharga serta menyebabkan populasi spesies terancam langka dan bahkan menjadi punah. Pengeksploitasian sumber daya laut secara lanjut akan mengakibatkan dampak perubahan terhadap ekosistem, keseluruhan jaringan trofik dan habitat Crowder dan Murawski (1998). Banyaknya hasil tangkapan sampingan dan yang dibuang dapat menjadi ancaman yang serius bagi keanekaragaman hayati yang nantinya berdampak pada ekosistem sumberdaya hayati di perairan tersebut.

Selain bervariasinya jenis hasil tangkap-an alat penangkapan ikan gombang yang dapat menjadi potensi perubahan struktur komoditas ikan dan udang serta juga dapat menjadi penyebab kerusakan sumberdaya perikanan, ukuran hasil tangkapan sampingan dan hasil tangkapan yang dibuang masih di bawah ukur-an tingkat kedewasaan (under maturity size). Hal ini terindikasi dari banyaknya ikan-ikan kecil dan muda yang tertangkap (Gambar 4, 5, dan 6). Menurut Crowder dan Murawski (1998) dan Diamond et al. (1999) peningkatan kematian ikan muda dan juvenil akan memperlambat pro-ses pemulihan sumberdaya di suatu perairan akibat kelebihan tangkap (overfishing). Selain itu, banyaknya jenis ikan, kepiting dan udang berukuran kecil dan muda tertangkap, tentunya akan bertolak belakang pula dengan konsep penangkapan ikan yang bertanggung jawab untuk perikanan yang berkelanjutan. Fenomena serupa juga dilaporkan oleh Cedrola et al. (2005); Borges et al. (2005), dan Fonseca et al. (2005) yang mana hasil tangkapan sampingan menjadi masalah pengelolaan perikanan tang-kap komersial seperti: pukat, jaring lingkar dan semua jenis alat penangkapan ikan. Hasil tangkapan sampingan terdiri dari ikan muda yang belum dewasa, dan berpotensi menye babkan stok perikanan di daerah perairan penangkapan menurun.

\section{SIMPULAN}

Berdasarkan komposisi proporsi hasil tangkapan pukat hela terdapat 41 jenis yang tertangkap, yang terdiri dari 6 jenis hasil tangkapan utama (main catch), 10 jenis hasil tangkapan sampingan (by-catch) dan 25 jenis hasil tangkapan yang dibuang (discard). Persentase jumlah hasil tangkapan yang dibuang mendominasi keseluruhan hasil tangkapan sebesar $61,10 \%$, dilanjutkan dengan hasil tangkapan utama sebesar 36,35\% dan hasil tangkapan sampingan sebesar $2,25 \%$. Hasil tersebut menunjukkan bahwa alat tangkap pukat hela yang ada di Kabupaten Tanjung Jabung Barat berpotensi merubah struktur keanekaragaman hayati perairan yang akan berpengeruh terhadap ekosistem sumberdaya hayati di perairan.

\section{UCAPAN TERIMA KASIH}

Ucapan terima kasih penulis sampaikan kepada nelayan yang mengoperasikan alat tangkap Pukat hela yang ada di Kabupaten Tanjung Jabung Barat sehingga penelitian ini terlaksana dengan baik. 


\section{DAFTAR PUSTAKA}

Alverson, D. L., Freeberg, M. H., Pope, J. G., \& Murawski, S. A. (1994). A Global Assessment of Fisheries Bycatch and Discards. FAO Fisheries Technical Paper No. 339. Rome: FAO.

Alverson, D. L., \& Hughes, S. (1996). Bycatch: from Emotion to Effective Natural Resource Management. Fish Biology and Fisheries. 6(4): 443462. DOI : https://doi.org/10.1007/BF00164325.

Borges, L., Rogan, E., \& Officer, R. (2005). Discarding by The Demarsal Fishery in The Waters Around Ireland. Fisheries Research. 76: 1-13. DOI: 10.1016/j.fishres.2005.05.011

Broadhurst, M. K., Millar, R. B, Wooden, M. E. L., \& Macbeth, W. G. (2006). Optimising Codend Configuration in a Multispesies Demarsal Trawl Fishery. Fisheries Management and Ecology. 13: 81-92. DOI : https://doi.org/10.1111/j.13652400.2006.00479

Cedrola, P. V., Gonzalez, A. M., \& Pettovello, A. D. (2005). Bycatch of Skates (Elasmobran-chii: Arhynchobatidae, Rajidae) in The Patagonia Red Shrimp Fishery. Fisheries Research. 71: 141-150. DOI https://doi.org/10.1016/j.fishres.2004.08.031

Crowder, L., \& Murawski, S. (1998). Fisheries Bycatch: Implications for Management. Fisheries 23(6): 8-16. DOI: https://doi.org/10.1577/15488446

Diamond, S., Crowder, L., \& Cowell, L. (1999). Catch and By-catch: The Qualitative Effects of Fisheries on Population Vital Rates of Atlantic Croaker. Transactions of the American Fisheries Society. 128: 1085-1105. DOI : https://doi.org/10.1577/15488659

Eayrs, S. (2005). A Guide to Bycatch Reduction in Tropical Shrimp-Trawl Fisheries. Rome, Italy: Food and Agriculture Organization (FAO) of the United Nations.

Fonseca, P., Campos, A., Larsen, R. B., Borges, T. C., \& Erzini, K. (2005). Using A Modified Nord-more Grid for By-catch Reduction in The Portuguese Crustacean-trawl Fishery. Fisheries Research. 71: 223-239. DOI: 10.1016/j.fishres.2004.08.018

Grimaldo, E., \& Larsen, R. B. (2005). The Cosmos Grid: A New Design for Reducing By-catch in The Nordic Shirp Fishery. Fisheries Research. 76: 187197. DOI: $10.1016 / \mathrm{j}$.fishres.2005.06.010

Hall, M. A., Alverson, D. L., \& Metuzal, K. I. (2000). By-catch; Problems and Solutions: Seas at Millennium: An Environmental Evalua-tion. In: Sheppard, C.R. (Ed.), Global Issues and Processes.

Hall, S. J., \& Mainprize, B. M. (2005). Managing Bycatch and Discards: How Much Progress Are We Making and How Can We Do Better? Fish Fish. 6(2): 134-155. DOI: https://doi.org/10.1111/j.1467-2979.2005.00183

Harrington, J. M., Myers, R. A, \& Rosenberg, A. A. (2005). Wasted Fishery Resources: Discard By- catch in the USA. Fish and Fisheries. 6: 350-361. DOI: 2979.2005.00201

Harris, A., \& Huang, A. (2001). Assessing the Effect of Fishing on Non-target Spesies in Commonwealth Fisheries. Report to the Fisheries Resources Research Fund. Australian Department of Agriculture, Fisheries and Forestry, May 2001, Canberra.

Jennings, S. (2005). Indicators to Support An Ecosystem Approach to Fisheries. Fish and Fisheries. 6: 212-232. DOI: 10.1111/j.1467-2979.2005.00189

Jennings, S. (2007). Reporting and Advising on the Effect of Fishing. Fish and Fisheries. 8: 269-276. DOI: $10.1111 / \mathrm{j} .1467-2679.2007 .00250$.

Kelleher, K. (2005). Discards in the World's Marine Fisheries: An Update. FAO Fisheries Technical Paper No. 470. Rome, Italy: Food and Agriculture Organization of the United Nations.

Krebs, C. J. (1985). The Experimental Analysis of Distribution and Abudance. Ecology. New York: Harper dan Row.

Nofrizal \& Arimoto, T. (2017). Histological Approach on the Lateral Line Organ of Jack Mackerel (Trachurus japonicas) for Mechanical Sensing in Swimming Behavior. Journal Sustainable Science and Management. 12(1): 23-29.

Nofrizal, Romie, J., Yani, A. H., \& Alfin. (2018). Hasil tangkapan sampingan (bycatch dan discard) pada alat tangkap gombang (fulter net) sebagai ancaman bagi keslestarian sumber daya perikanan. Marinr Fisheries 9(2):221-233.DOI: https://doi.org/10.29244/jmf.9.2.221-233

Purbayanto, A., S. H., Wisudo, J., Santoso, M., Wahyuni, R. I., Wahyu, Dinarwan, Zulkarnain, Sarmintohadi, A. D., Nugraha, D. A., Soeboer, B., Pramono, A., Marpaung \& M. Riyanto. (2004). Pedoman Umum Perencanaan Pengelolaan dan Pemanfaatan Hasil Tangkap Sampingan Pukat Udang di Laut Arafura. Diterbitkan oleh Dinas Perikanan dan Kelautan Provinsi Papua bekerjasama dengan PT. Sucofindo. Jakarta.

Svane, I. B. (2005). Occurrence of Dolphins and Seabirds and Their Consumption of By-catch During Prawn Trawlingin Spencer Gulf, South Australia. Fish Res. 76(3): 317-327. DOI: 10.1016/j.fishres.2005.07.012

Vestergaard, N. (1996). Discard Behaviour, Highgrading and Regulation: The Case of the Greenland Shrimp Fishery. Mar. Resour. Ecol. 11: 247-266.

Watson, R., Pauly, D. (2001). Systematic Distor-tions in World Fisheries Catch Trends. Nature. 414(6863): 534-536. DOI: 10.1038/35107050

Zeller, D., Pauly, D. (2005). Good News, Bad News: Global Fisheries Discards are Declining, but so are Total Catches. Fish and Fisheries. 6: 156-159. DOI: https://doi.org/10.1111/j.1467-2979.2005.00177 